\title{
方向性を持つ底面粗度を用いた潮汐残差流の創造と制御 \\ On Creation and Control of Tidal Residual Current \\ by Bottom Roughness with Directional Characteristic
}

\author{
小松利光* · 矢野真一郎** · 鞠承淇 $* * *$. 小橋乃子 $* * * *$ \\ By Toshimitsu KOMATSU, Shinichiro YANO, Seung-Gi GUG and Naoko KOHASHI
}

\begin{abstract}
Water pollution in a semi-enclosed sea area such as a bay or a fishing port due to stagnancy of water has been a serious problem on water environment. We proposed a new method to activate the tidal exchange between an inner and an outer sea area by creation and control of a tidal residual current. In this new method, the tidal residual current is produced and controlled by artificial structures, which change properties of resistance according to a direction of flow, set on the bottom. In this study, several tidal current and particle movement simulations with various arrangements of artificial bottom roughness in a semi-enclosed model bay were carried out. As a result of many kinds of numerical experiments, it becomes clear that it is possible to generate the tidal residual current and to activate the tidal exchange by only operation of bottom roughness.
\end{abstract}

Keywords :tidal exchange, tidal residual current, Euler-Lagrange method, bottom roughness, water purification

\section{1.まえがき}

内湾や漁港のような閉鎖性海域では、湾内水の停滞に起因する水質の悪化が問題となっている。近年、人工構 造物を用いて潮流を制御し、外海との海水交換を活発化させて水質の改善を図ろうとする方法が幾つか提案され ている。例えば、上嶋ら”は湾内もしくは湾口付近に防波堤のような構造物を設置し湾内の潮流を制御する方法 を、村上ら2は湾口に設置されている防波堤の形状による制御法を、大谷ら゙はは湾口部の両岸に潮流の剥離を促進 させる構造物を設置する方法を提案している。また、粟谷・小松ら4は湾内に建設された人工島の背後にできる停 滞水域の流動を活発化するために、岸壁に流れの方向により抵抗特性の異なる2 次元構造物を配置し、岸に沿っ て潮汐残差流を発生させる方法を提案している（図一1参照）。これらの方法には、長大構造物を建設すること による景観上の問題や潜堤にした場合の船舶の航行の安全性の問題が、また湾口部の改变による方法や側岸に方 向特性のある構造物を設置する方法では潮流を制御できる範囲が限定されてしまうなどの問題がある。また、全 てに共通する問題点としては、万が一予想と異なる効果が発生してしまった場合に簡単には構造物を除去するこ とが出来ないことがあげられる。本研究では、上述の問題点を全て解決すべく、流れの方向により抵抗特性が異 なる比較的小規模な構造物（以下、底面粗度と呼ぶ）を海底面に並べて沈設することにより、湾内に発生する潮 汐残差流を制御するという方法を提案し、その効果について数值解析により検討してみた。

$\begin{array}{llllll}* & \text { 正会員 } & \text { 工博 } & \text { 九州大学教授 } & \text { 工学部建設都市工学科（テ812-81 } & \text { 福岡市東区箱崎 6-10-1） } \\ * * & \text { 正会貝 } & \text { 工修 } & \text { 九州大学助手 工学部建設都市工学科 } & \\ * * * & \text { 学生員 } & \text { 工修 } & \text { 九州大学大学院 工学研究科博士後期課程 } & \\ * * * * & \text { 学生員 } & \text { 九州大学大学院 工学研究科修士課程 } & \end{array}$




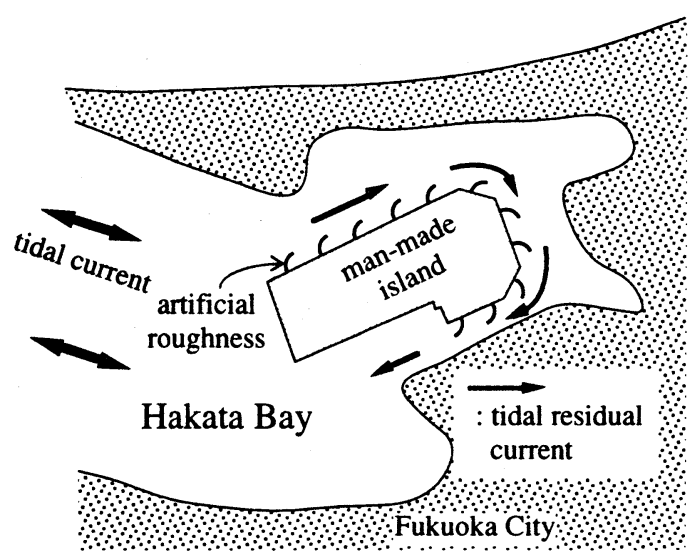

図一１側壁人工粗度による潮汐残差流の制御法概念図

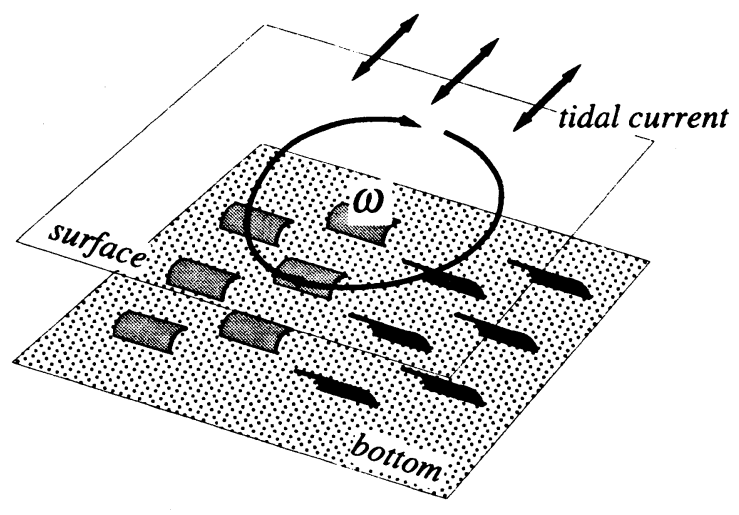

図一－海底人工粗度による潮汐残差流の制御法概念図

\section{2. 底面粗度について}

本研究で提案する方法は、図一 2 に示すように流れの方向により抵抗が異なる3 次元底面人工粗度を湾内の 海底面に配置し、潮流が上げ潮・下げ潮のどちらであっても常に同じ符号の渦度を発生させることにより、一 周期平均で得られる潮汐残差流を創造・制御しようとするものである。この方法は、湾内において底面粗度を 基本的に自由に配置することが可能であるので、海水交換に有利になるように潮汐残差流のパターンを自由に デザインすることを可能とするものである。粗度形状の工夫次第でより大きな粗度差を獲得でき、効率よく潮 流を制御できることが期待されるが、その形状については並行して研究中5). 6)であり現在のところまだ最適形 状の決定にまでは至っていない。

粟谷・小松ら 4 は流れの方向により最も抵抗差が大きい側壁 2 次元構造物について十数種類の形状に関して 実験的に調べ、1/2円筒もしくは1/4円筒の形状がそれらのうち最も有効であることを見出している。今回は底 面粗度についての情報が無いので、この実験結果を援用して議論を進める。底面粗度の高さを水深の 2 割程度 とした場合に、水深 $10 \mathrm{~m}$ の現場で得られる粗度差は、粟谷・小松らの実験結果より換算してManningの粗度係 数で0.06 程度である。船舶の航行の安全性を踏まえて粗度の高さを水深の1〜2割程度に設定すること、3 次元 構造物を底面粗度として想定していることなどから、これより小さな粗度係数差しか得られない可能性があ る。そこで、今回は底面粗度により得られる粗度係数差を $0.01 に$ 設定して、底面粗度の効果の検討を行った。 今回の検討に用いた平面 2 次元モデルでは、海底摩擦による底面せん断力は次式の様に評価される。

$$
\frac{\tau_{b}}{\rho}=\gamma_{b}^{2} \mathbf{U}|\mathbf{U}|
$$

ここで、 $\tau_{b}=\left(\tau_{b x}, \tau_{b y}\right):$ 底面せん断カベクトル、 $\gamma_{b}^{2}:$ 海底摩擦係数、 $\mathbf{U}=(U, V)$ : 水深平均流速ベクトル、 $\rho$ ： 海水の密度である。

海底摩擦係数は熟見らりによりまとめられた過去の代表的な観測結果より、10-4〜10-2のオーターと幅広い 值が得られている。今回は通常用いられている $\gamma_{b}^{2}=0.0026$ を基準值として用いた。海底摩擦係数とManning の 粗度係数 $n$ の関係は次式で表される。

$$
\gamma_{b}^{2}=\frac{n^{2} g}{h^{1 / 3}}
$$

よって、水深を $10 \mathrm{~m}$ とした場合には粗度係数は $n=0.024$ と換算される。今回は、底面粗度を設置した場合の海 底摩擦係数がどの程度になるのかがまだ明らかでなかったため、 $n=0.024 を$ 底面粗度を設置していない通常の 海域ならびに底面粗度を設置した海域における順流（抵抗が小さい方向の流れ）に対する粗度係数とした。 よって、逆流（抵抗が大きい方向の流れ）に対する粗度係数は $n=0.034\left(\gamma_{b}^{2}=0.0053\right)$ となる。 


\section{3. 潮流シミュレーション}

方向特性を持つ底面粗度の配置により、潮汐残差流のパターンを変え得るかどうかを確かめるために、図一 3 に示したモデル湾においてADI 法による平面 2 次元潮流シミュレーションを行った。計算条件は、計算格子 間隔 : $\Delta x=\Delta y=500(\mathrm{~m})$, 時間格子間隔 : $\Delta t=15(\mathrm{sec}$.$) , 渦動粘性係数 : v_{t}=100.0\left(\mathrm{~m}^{2} / \mathrm{sec}.\right)$, コリオリ係数 $: f=0$ $\left(\mathrm{sec}^{-1}\right)$ とした。境界条件は、開境界 B-C で振幅 : $a=1.0(\mathrm{~m})$, 周期 $: \mathrm{T}=12 \mathrm{hr} .25 \mathrm{~min}$. の正弦波を与 え、開境界 A-B, C-D で $U=0, d V / d x=0$ を、壁面 境界上では no-slip 条件を与えている。

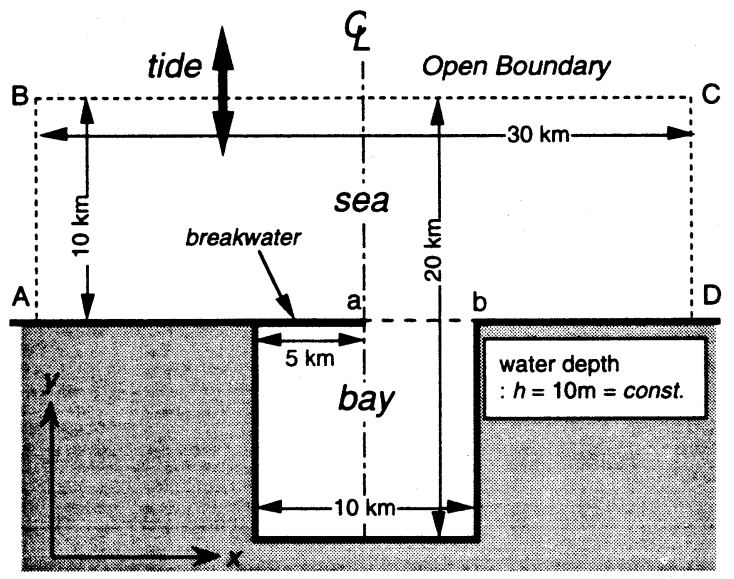

図ー3 モデル湾概略図
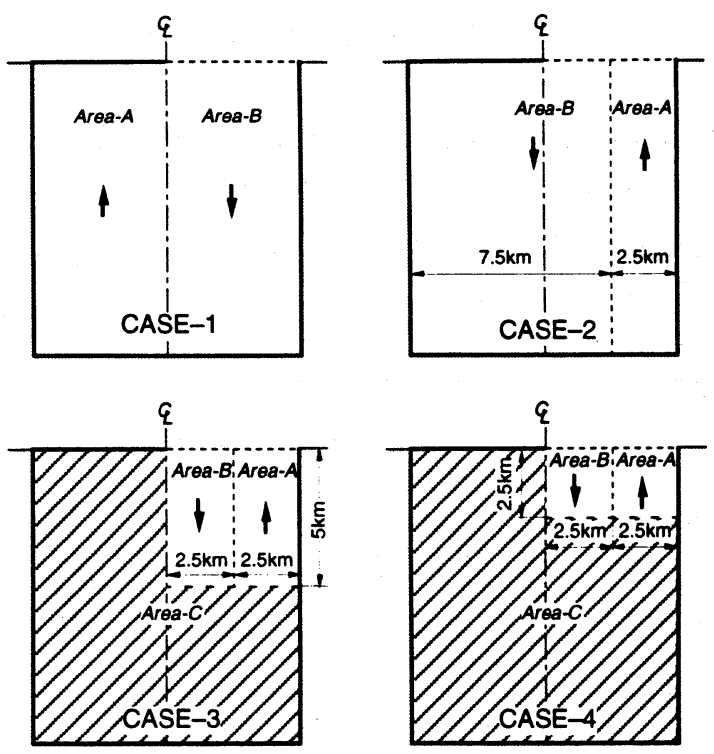

图ー4 モデル湾における底面粗度の配置

今回は、湾内のみに底面粗度を配した場合を検討の対象とし、图ー4に示す CASE-1４ と CASE-0 として 粗度を配置しない場合の $5 つ$ つースについて計算を行った。粗度の配置の仕方は、図一 4 に示すArea-A,Bに ついては矢印の方向を順流方向に、例えば Area-A では流速のy軸の正方向成分に対して $\gamma_{b}^{2}=0.0026$ を負の 方向に対して $\gamma_{b}^{2}=0.0053$ を与えて抵抗差を表している。ただし、CASE-4については逆流に対して粗度係数 差を 2 倍にして $\gamma_{b}^{2}=0.0088(n=0.044)$ を与えた。また、斜線部分のArea-C は粗度を配置しない水域である。

1 周期分の潮流の計算結果を平均することにより得られた潮汐残差流とその流線の計算結果をCASE-0, 1, 4 についてのみ図ー5に示す。CASE-1では、CASE-0で湾内に既に存在していた湾スケールの循環流が強化され

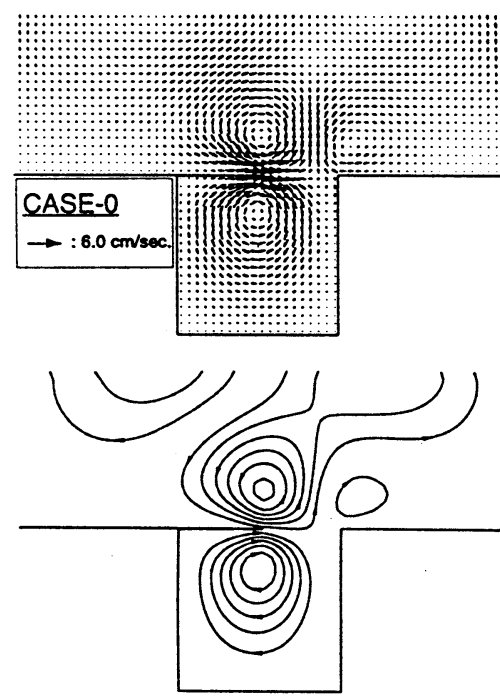

(a) CASE-0

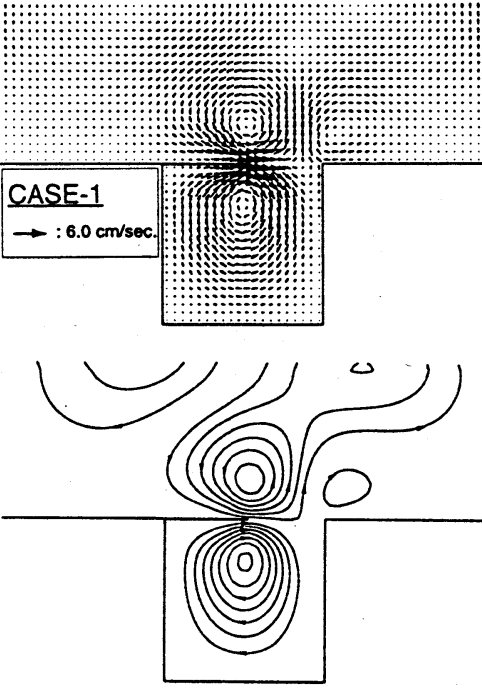

(b) CASE-1
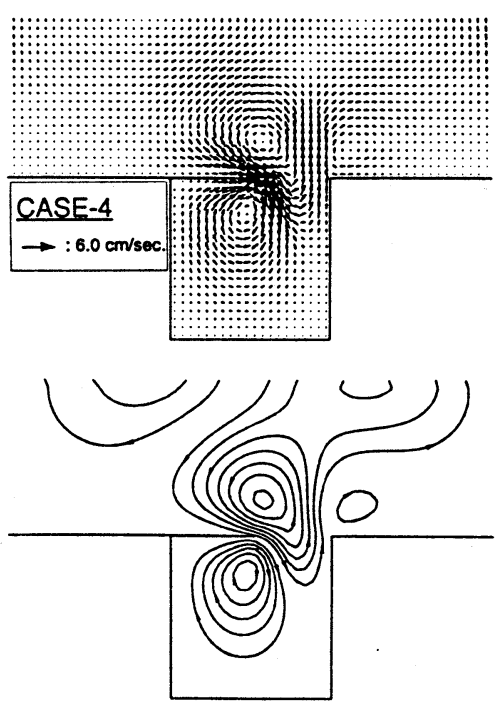

(c) CASE-4

図一 5 潮汐残差流の計算結果（上段：ベクトル困、下段：流線困） 
ているのが分かる。紙幅の関係上示してはいないが CASE-2, 3 では、CASE-4の結果と同じように外海に発達 した循環流が湾内部にまで侵入していた。このことは、粗度の配置を工夫することと抵抗差の大きい形状を持 つ粗度を開発することで、潮汐残差流をより効率よく制御できることを示唆している。また、CASE-1 のよう に湾内の循環流を強化するだけではなく、CASE-2, 3,4のように湾口付近の外海の循環流を変化させて湾内へ 侵入させ湾内の循環流と混合させることが外海との海水交換をより活発化させるものと予想される。

\section{Euler-Lagrange 法による海水交換率の評価}

\subsection{Euler-Lagrange 法と海水交換率}

次に、底面粗度による潮汐残差流の制御が海水交換へ及ほす影響について調べるために、湾内に標識粒子を 配置し粒子追跡計算（Euler-Lagrange 法）を行った。各時刻における粒子の位置ベクトルは (3) 式により計算 された。

$$
\mathbf{X}(t+\Delta t)=\mathbf{X}(t)+\Delta t \cdot \mathbf{U}(\mathbf{X}(t), t)+\frac{\Delta t^{2}}{2} \cdot \frac{D \mathbf{U}(\mathbf{X}(t), t)}{D t}
$$

ここで、

$$
\frac{D U_{i}(\mathbf{X}(t), t)}{D t}=\frac{\partial U_{i}(\mathbf{X}(t), t)}{\partial \mathrm{t}}+\mathbf{U}(\mathbf{X}(t), t) \cdot \nabla_{H} U_{i}(\mathbf{X}(t), t)
$$

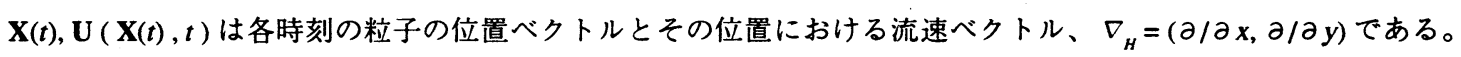

3.において各CASE について得られた1 周期分の流速データを基に標識粒子の移動は計算された。計算時間間 隔は粒子の移動距離が1メッシュ以上にならないように $\Delta t=150 \mathrm{sec}$. と設定された。境界付近の処理は、壁面で粒 子は完全反射し、開境界から流出した粒子は再び計算領域内へは戻らないものとした。また、乱流拡散・移流分 散による効果は今回の計算には取り入れなかった。なお、乱れの海水交換率への影響についてはAwajisににより言 及されており、それによると粒子の拡がりには影響するが海水交換率にはあまり大きく影響はしないと報告され ている。

海水交換率を評価する境界線は図ー 3 に示す湾口部のライン $\mathrm{a}-\mathrm{b}$ とする。標識粒子をラインより湾内側全域に $1 メ ッ シ ュ ~(500 \mathrm{~m} \times 500 \mathrm{~m})$ 当たり 25 個、計 10,000 個配置し、下げ潮最強時から始まる 1 潮汐間にわたって各粒 子の軌跡を計算する。今里》は潮汐の 1 周期間で境界線よりも外側へ出た粒子が代表する湾内水の体積が最大とな るとき（通常は最干潮時付近）の体積を $V_{\text {max }} 、 1$ 周期後の下げ潮最強時にライン外側へ残っている粒子が代表す る体積を $V_{\text {res }}$ として、海水交換率を次式で定義している。

$$
E X=\frac{V_{\text {res }}}{V_{\max }}
$$

本研究では、この海水交換率EXにより底面粗度の効果を評価した。

粒子追跡計算結果の一例としてCASE-0 とCASE-4 の $V_{\text {max }}$ と $V_{\text {res }}$ が得られた時刻の湾口部付近の粒子の分布を 図一6に示す。また、各CASEにおいて得られた $V_{\max }, V_{r e s}$, 海水交換率 $E X$ の値を表ー 1 に示す。この結果による と、CASE-4が最も海水交換が活発化されており、海底粗度を敷設しない場合(CASE-0)の約 2 倍の交換率が得ら れている。CASE-4 は粗度を配置した面積は最も小さかったが粗度差を他のCASEより大きく設定したものであっ たことより、海水交換率を大きくするには湾口付近に局 所的に強い粗度差を与えて渦度の発生を促進させること が重要であることが推定できる。

\begin{tabular}{|c|c|c|c|}
\hline$\overline{\text { CASE }}$ & $\begin{array}{c}V_{\max } \\
\left(10^{6} \mathrm{~m}^{3}\right)\end{array}$ & $\begin{array}{c}V_{\text {res }} \\
\left(10^{6} \mathrm{~m}^{3}\right)\end{array}$ & $\begin{array}{l}E X \\
(\%) \\
\end{array}$ \\
\hline 0 & 103.1 & 13.9 & 13.5 \\
\hline 1 & 103.0 & 14.7 & 14.3 \\
\hline 2 & 103.4 & 19.1 & 18.5 \\
\hline 3 & 103.2 & 19.2 & 18.6 \\
\hline 4 & 103.2 & 26.1 & 25.3 \\
\hline
\end{tabular}

\section{2 湾内水の滞留について}

次に、湾内水の長期的な交換能力について比較する ために、粒子追跡計算を60周期（約1ヶ月）にわたって 

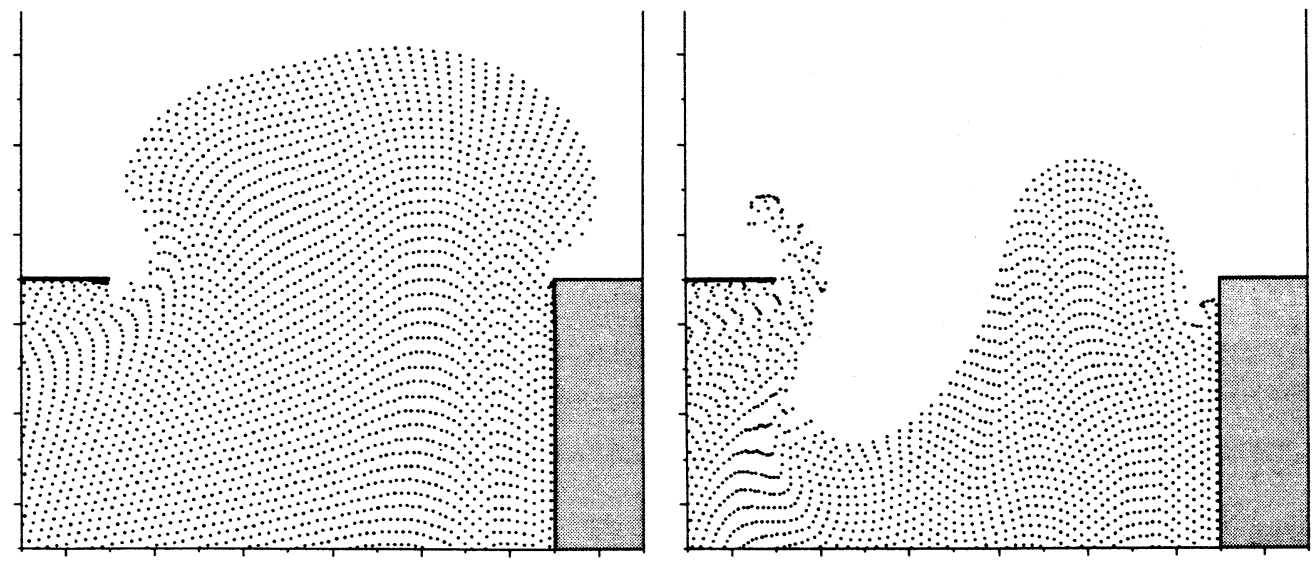

図-6 粒子追跡計算の計算結果（CASE-4）（左図： $V_{\max }$ が得られた時刻、右図：1 周期後の最大下げ潮時）
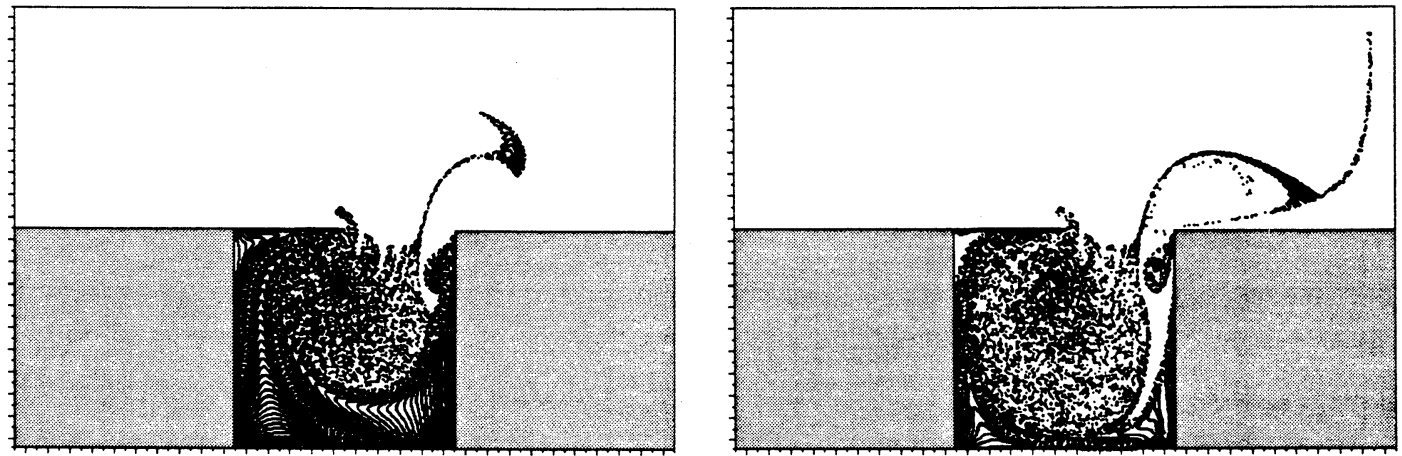

(a) CASE-0：15 周期後

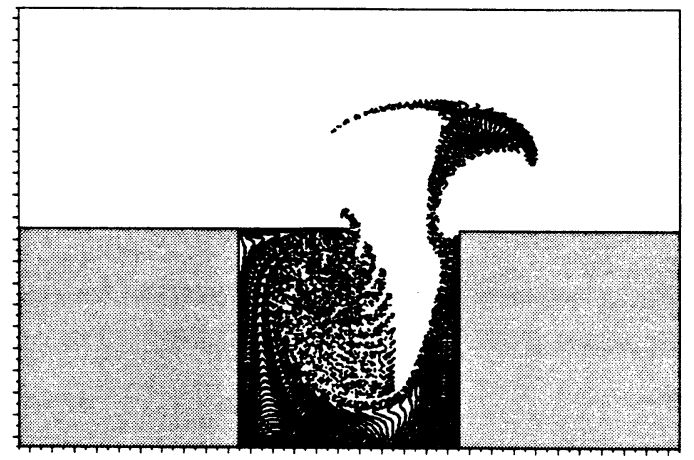

(b) CASE-0：60 周期後

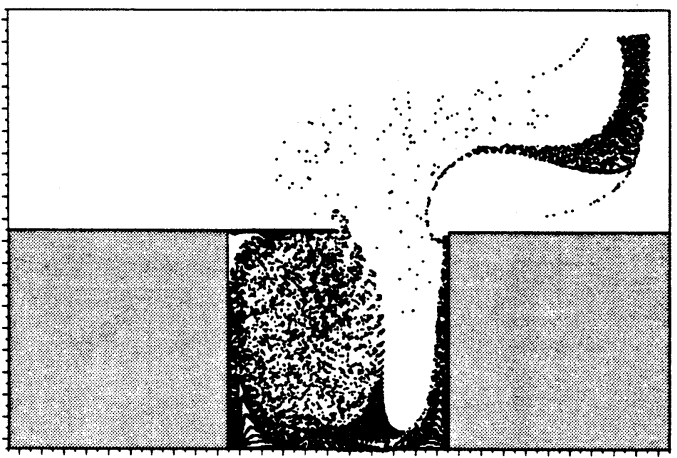

(c) CASE-2: 15 周期後

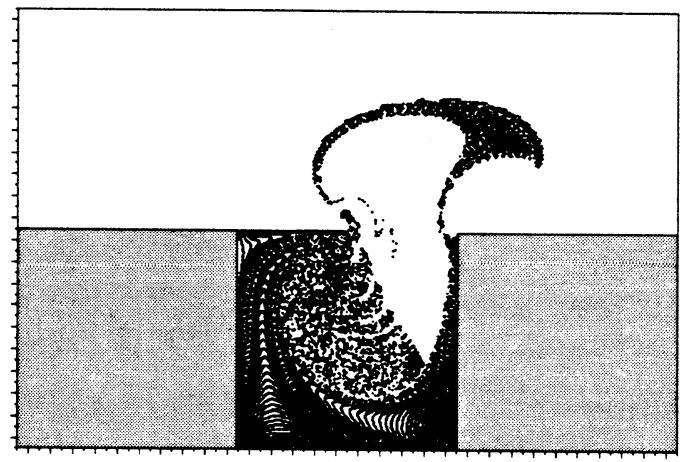

(d) CASE-2:60周期後

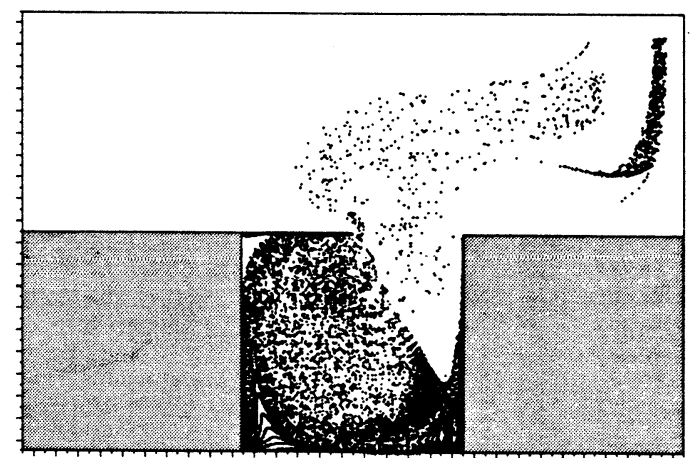

(f) CASE-4:60 周期後

(e) CASE-4 : 15 周期後

図-7 粒子追跡計算の計算結果（上段：CASE-0、中段：CASE-2、下段：CASE-4） 
行った。初期時刻から 15 周期後と60周期後の最大下げ 潮時の粒子の分布をCASE-0，2，4について図一7に示 す。また、初期時刻に湾内に配置された全粒子のうち 各周期の最後の時刻（最大下げ潮時）に湾内に存在し ている粒子残存率の経時変化を図一 8 に示す。

これらの結果を比較すると、比較的初期の段階では 海水交換率の大きいCASE-4が湾内水を外海に流出さ せる能力が大きいことが分かるが、10周期を過ぎると 外海への流出が少なくなっている。20周期程度からは むしろCASE-2の方が残存率が下がっており、長期間

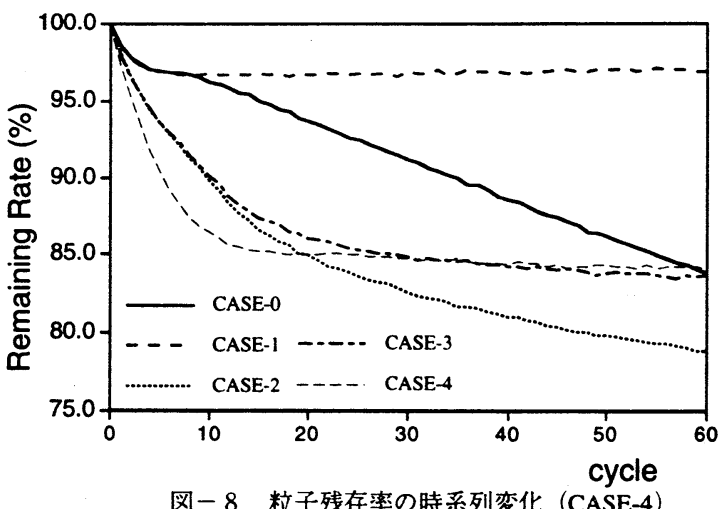

図-8 粒子残存率の時系列変化 (CASE-4) にわたる交換能力は最も優れているという結果になった。CASE-2が湾口から湾奥まで粗度を配置していたの に対しCASE-4が湾口部付近にのみ強い抵抗差を与えていたことを考えると、閉鎖性海域の海水交換の促進に は湾口部の海水交換能力の引き上げと湾全体にわたるスケールの循環流により湾奥部の海水を湾口部付近に運

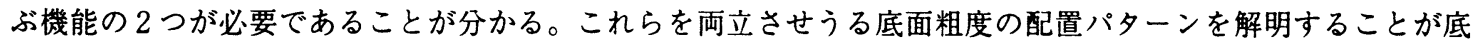
面粗度による海水交換促進技術の発展にとって急務であると言えよう。

\section{5. 結論}

方向特性を持つ底面粗度を湾内に配置することにより潮汐残差流のパターンをコントロールできることが数 值解析により分かった。また、海水交換を活発化出来ることも粒子追跡計算により確認された。このことは、 従来空間的に一様として与えられていた海底摩擦係数の分布の重要性をも示唆するものである。本研究は比較 的単純な地形をもち成層化の影響もないものと仮定されたモデル湾におけるものであり、比較的有利な条件下 で検討されている。今後は、実際の閉鎖性内湾における検討と 3 次元シミュレーションによる成層や風の影響 を取り入れた検討を行う必要があると考えられる。

最後に、本研究は（財）服部報公会の研究助成の下に行われた。記して謝意を表します。

\section{参考文献}

1). 上嶋英機、橋本英資、田辺弘道、宝田盛康：流況制御構造物設置による流況制御技術の効果検証実験一瀬戸 内海大型水理模型による別府湾・大阪湾での実駼結果一, 海岸工学論文集, 38, pp. 851-855, 1991.

2). 村上和男、菅沼史典、宮崎啓司、山田邦明、清水勝義 : 潮汐エネルギーを利用した海水交換促進に関する 水理模型実験, 水工学論文集, 37, pp. 411-418, 1993.

3). 大谷英夫、高山百合子、石野和男、勝井秀博、宝田盛康 ：流況制御のための湾口渦と水平循環流に関する 実験的研究, 海岸工学論文集, 42, pp. 1221-1225, 1995.

4). 粟谷陽一、小松利光、川崎昌三、朝位孝二、藤田和夫：人工粗度を用いた恒流の生成に関する研究, 水工学 論文集, 39, pp. 589-594, 1995.

5). 小橋乃子、鞠承淇、小松利光、矢野真一郎、藤田和夫 : 方向性をもつ海底人工粗度による潮汐残差流の制御 について, 土木学会第51 回年次学術講演会, II, pp. 212-213, 1996.

6). 小松利光、矢野真一郎、小橋乃子、鞠承淇、藤田和夫 : 流れの方向により抵抗特性の異なる人工粗度の開 発, 水工学論文集, 41, 1997.

7). 䳓見栄一、橋間元徳：沿岸海域における海底摩擦係数の評価, 公害資源研究所彙報, 12 (2), pp. 63-74, 1982.

8). Awaji, T. : Water Mixing in a Tidal Current and the Effect of Turbulence on Tidal Exchange through a Strait, J. Phys. Oceanogr.,Vol.12, pp. 501-514, 1982.

9). 今里哲久：海水交換の概念と交換率, 沿岸海洋研究ノート30 周年記念特別号, pp. 111-123, 1993. 